\title{
流し込みレジンの重合時に生ずる変形の可能性について
}

\begin{tabular}{|c|c|c|c|c|c|c|c|}
\hline 守川 & 雅男* & 益田 & 正美* & 堀 & 孝良* & 山崎 & 純* \\
\hline 鹫 & 郷一－ * & 林 & 和夫* & 三宅 & 茂樹** & 滝 & 豊** \\
\hline 田田 & 静夫* & 井上 & 一郎*** & & & & \\
\hline
\end{tabular}

\section{Dimensional Change in Curing Processes of Pour Type Resin}

\author{
Masao Morikawa*, Masami Masuda*, Takayoshi Hori*, \\ Atsushi Yamazaki*, Goichi Howashi*, Kazuo Hayashi*, \\ Shigeki Miyake ${ }^{* *}$, Yutaka Taki**, Shizuo Toyoda * \\ and Katsuichiro Inoue ***
}

\section{1. まえがき}

1967 年, Winkler ${ }^{1)}, S^{2}$ hepard $\left.{ }^{2}\right)$ らによって, 従来よ り使用されてきた加熱加圧型レジンにかわる流し込みレ ジンが紹介された.このレジンは Polymer に対する Monomer の量 (L/P) が多いためにキャストし易いこ と，常温で重合できるために寸法精度が高いこと，鋳型 材として粘弾性的性質に富んだ寒天を用いるために従来 の石こう鋳型で重合したレジンに比へて義歯苗肉面，粘 膜面が比較的滑沢になり重合後の技工的操作が容易なこ となど数多くの長所を持っといわれている. その反面, 加熱加圧型レジンの場合に比べて床の機械的强度が幾分 劣ること, 重合後咬合高径の減少, 人工歯の位置の移動 がおこり易いこと、レジン歯と床の接着がやや不確実な こと，加圧しないため重合体に気泡が発生し易いことな どの短所も挙げられている.これらの短所はいずれも材 料の重合収縮, あるいはそれによって生ずる変形に起因 するものと思われるが，これらについて定量的に測定し た研究は少なく、、ぜんとして不明な点が多い3 11).

* 九州歯科大学第 1 補綴学教室 (主任: 豊田静夫教授)

** 九州画科大学大学院歯学研究科補経学専攻

*** 九州歯科大学理工学教室

* First Department of Prosthetic Dentistry (Chief: Prof. Shizuo Toyoda), Kyushu Dental College

** Kyushu Dental College Graduate School of Dentistry (Major in prosthodontics)

*** Department of Dental physicotechnology, Kyushu Dental College. 昭和 51 年 1 月 12 日受付
そこで著者らは，その手初めとして今回，長さ，径の 異なる 9 種類の単純な棒状基準金型を基にしてレジン片 を作製し，重合時に生ずる収縮量から各基準金型につい て収縮の生じ方, 重合体の変形の可能性について, その 挙動を検討したので報告する.

\section{2. 実験方法}

\section{2-1 測定装置}

本実験にわいては，基準金型を用いてレジン片を作製 し，それらの基準金型に対する膨縮量を計測することに より種々の比較検討をおこなつた. 計測には形状測定器 （小坂研究所製 $\mathrm{EF}-1$ 型）ならびに X-Y レコーダー（渡 辺測器製作所製 W-X 432 型) を用いた. 方眼紙上にX 軸方向 5 倍, Y 軸方向 50 倍で記録して扔き, 倍率 10 倍 のルーペを用いて読取つた，装置の写真ならびに原理図 にっいては, 図1，2 に示す。

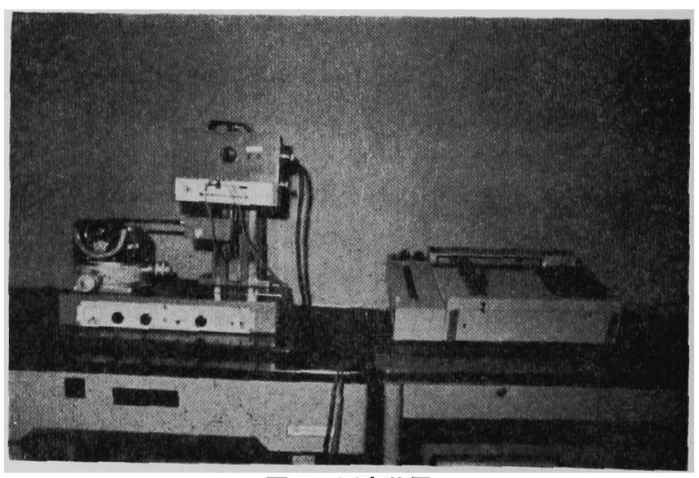

図 1 测定装周 


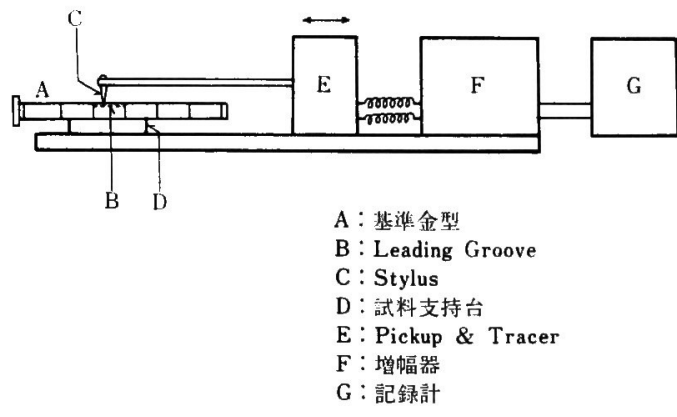

図 2 測定装置原理図

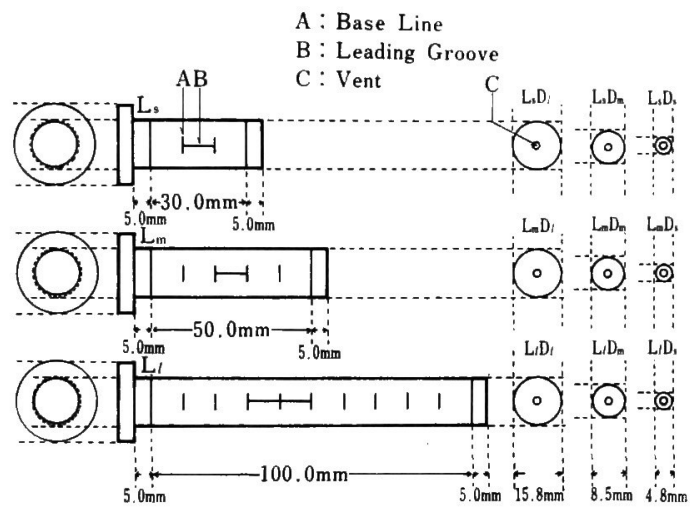

図 3 基準金型の種類

\section{$2-2$ 実験装置}

\section{2-2-1 基準金型}

本実験には, 長さを $100 \mathrm{~mm}$ (最長), $50 \mathrm{~mm}$ (中間), $30 \mathrm{~mm}$ (最短) にし, それぞれの長さのものについて径 を $15.8 \mathrm{~mm}$ (最太), $8.5 \mathrm{~mm}$ (中間), $4.8 \mathrm{~mm}$ (最細) にした 9 種類の棒状基準金型を使用した。 これらについ ての模型図は図 3 に示寸. 以後, 最短一最太, 最短一中間, 最短一最細, 中間一最太, 中間-中間, 中閒一最細, 最長一 最太，最長一中間，最長一最細の各基準金型をそれぞれ $\mathrm{LsD} l, \mathrm{LsDm} ., \mathrm{LsDs}: \mathrm{LmD} l, \mathrm{LmDm}, \mathrm{LmDs}: \mathrm{L} l \mathrm{D} l$, $\mathrm{L} l \mathrm{Dm}, \mathrm{L} l \mathrm{Ds}$ と呼ぶことにする. 各基準金型の表面に は長軸と直角に Base Line を, 平行に Leading Groove をつけた.この Leading Groove は基準金型とそれよ り作製したレジン片の同一部位を測定できるようにした ものである、基準金型に対するレジン片の収縮量は形状 测定器の Stylus の尖端を Leading Groove に沿つて 移動させたときの Base Line 閒の長さの変化で測定し た. また基準金型の底部中央部には直径約 $1.5 \mathrm{~mm} の$ 孔があけてある.この孔は流し込みレジン用重合フラス

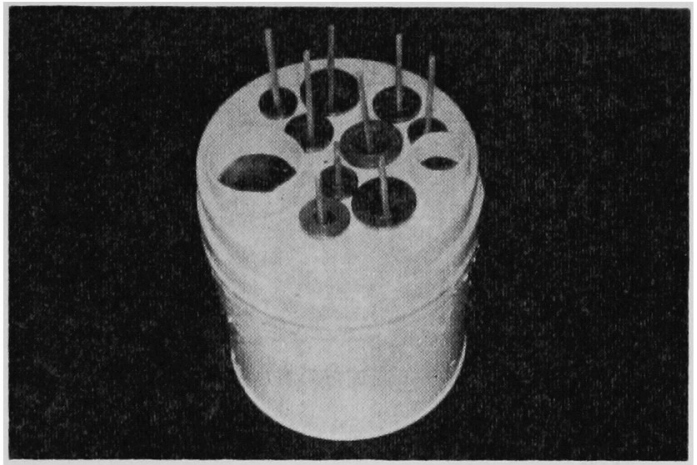

図 4 重合用フラスコならびに基準金型

コにその基淮金型を装着し，鋳型材である寒天を注入 し，冷却させた後基準金型をひき抜く際に生ずる寒天壁 との閒の陰圧を消去して, 寒天の変形を最小限にとどめ るためにつけた Vent である. 寒天注入時にはこの孔 を棒を用いて封じておき，寒天冷却後，まず棒を拔去し てつぎに基準金型を除去した. 図 4 は後述の重合用フラ スコに基準金型ならびに底部の Vent に栓をするための 棒を装着し, 寒天注入の準備のできた状態を示す.

2-2-2 重合用フラスコ

流し込みレジン重合用フラスコは上面に，各基準金型 間に十分な寒天の閒吵がとれると思われる位置に 9 種類 の基準金型の植立孔を設け，さらに寒天注入孔，寒天排 出孔ならびに空気抜き孔をつけたものを自作し本実験に 使用した.

\section{2-3 試験片作製}

流し込みレジン用鋳型材としては松風製キャストゲル を用いた. 寒天 $1.188 \mathrm{~g}$ に水 $200 \mathrm{cc}$ を加えメーカ指示 に従つて注入冷却後, 前述の順序で基準金型を抜去し た. また予備実験の結果, 寒天壁に付着した水分が試料 の形態に影響を及ぼすことがわかつたため，レジン注入 直前に綿花で軽く寒天壁の水分を拭き上げた. キャスト レジン（松風）の粉液比 (L/P) は $0.56,1.11$ とし, メ 一カ指示に従つて重合し, 重合後, 室温 $\left(25^{\circ} \mathrm{C}\right)$ で 30 分 間冷却した後直ちに計測した。なお計測した試料は，室 温 $\left(25^{\circ} \mathrm{C}\right)$ に保存して経時的変化む併わせて測定した.

\section{3. 実験結果}

3-1 長さの依存性について $(L / P=0.56)$

メーカ指示に従つて重合し, 室温 $\left(25^{\circ} \mathrm{C}\right)$ で 30 分閒 冷却後直ちに計測した. 収縮量の測定は鋳込口側からお こなつた. 径が最小の基淮金型 (LsDs, LmDs, LlDs) 


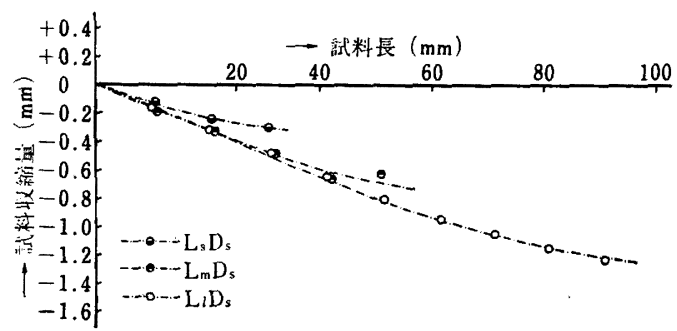

図 5 試料収縮量の長さ依存性

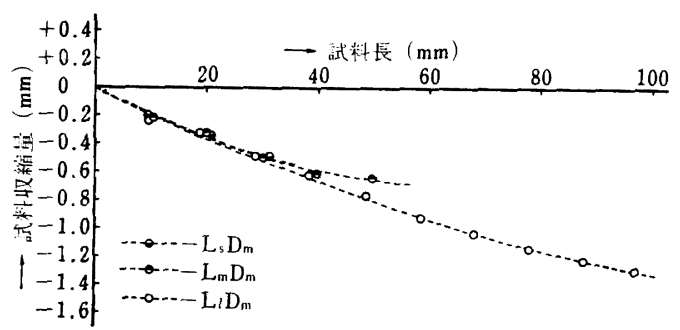

図 6 試料収縮量の長さ依存性

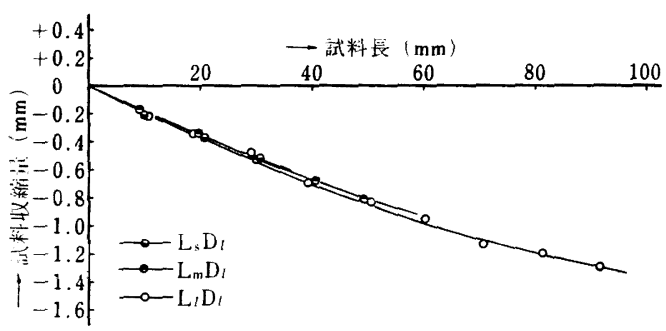

図 7 試料収縮量の長さ依存性

を用いて作製したレジン片（以後，それぞれをLsDs, Lm Ds, LlDs 試料と呼び, 以下これに準ずる) では, $L l D s$ 試 料が最も小さい収縮量示した(図 5 ). LsDm, LmDm, $\mathrm{L} l \mathrm{Dm}$ 試料では, 長さのちがいによる収縮量の差は, 前 試料間にみられた差より小さくなり，鋳込口からおよそ $30 \mathrm{~mm}$ 位のところまではほとんど同じ挙動を示した（図 6). $\mathrm{LsD} l, \mathrm{LmD} l \mathrm{~L} l \mathrm{D} l$ 試料の収縮量ではこれら 3 試 料間の差は，さらに小さくなつた（図７）.しかし，い ずれの試料においても長さの最も短いものが最も小さい 収縮量を示し, 長さが大になるに従つて収縮量も大きく なつた。これらの収縮量の変化をより見易くするために 收縮曲線上の各測定点で図上微分をおこなつた。これを 用いて各試料の収縮率をみると, LsDs 試料ではその值 は小さく，鋳込口からおよそ $20 \mathrm{~mm}$ 位まではほぼ一定 しており，それ以後历るやかな低下を示した. LmDs 試 料では, 鋳込口付近での収縮量の変化は LsDs 試料に比

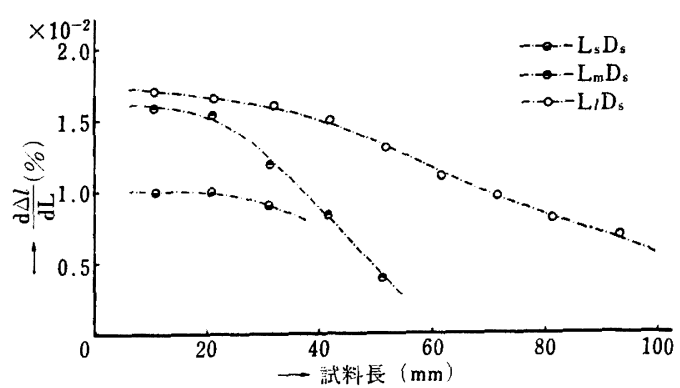

図 8 試料の収縮量変化の長さ依存性

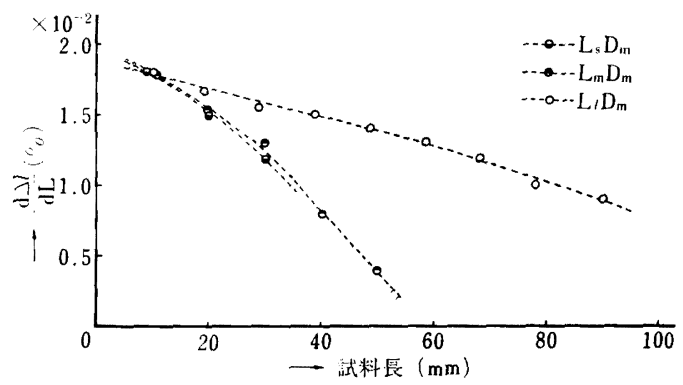

図 9 試料の收縮量変化の長さ依存性

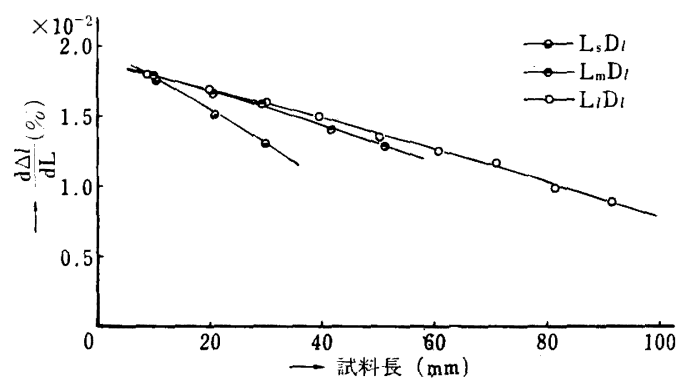

図 10 試料の収縮量変化の長さ依存性

して著しく大きく，鋳込口から遠ざかるに従つて急激な 低下を示した. LlDs 注試料， LmDs 試料ほど急激な収 縮率の低下はなく鋳込口より約 $30 \mathrm{~mm}$ のところまでは ほとんど一定した值を示し，それ以後はゆるやかに減少 した (図 8). LsDm, $\mathrm{LmDm}, \mathrm{LlDm}$ 試料では, 鋳込 口付近で高い収縮率を示したが，それより遠ざかるに従 つて漸次低下した．その低下の度合いは, LsDm, Lm $\mathrm{Dm}, \mathrm{L} l \mathrm{Dm}$ 試料の順に大であつた (図 9). $\mathrm{LsD} l, \mathrm{Lm}$ $\mathrm{D} l, \mathrm{~L} l \mathrm{D} l$ 試料においても同しような傾向を示したが, これら 3 試料間には前試料間にみられた程の収縮率の差 はみられなかつた（図 10).

3-2 径の依存性について $(L / p=0.56)$

LsDs 試料以外のものでは, 同一長さの試料間には収 


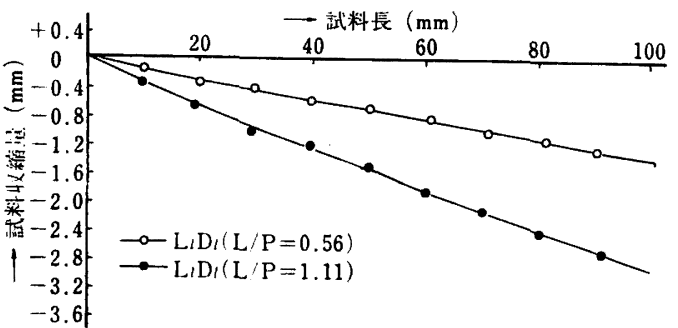

図 11 試料収縮量の粉液比による影響

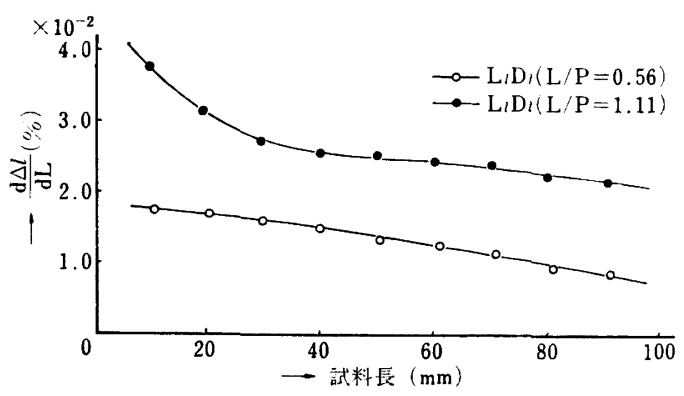

図 12 粉液比による収縮量の変化率

縮量の差はほとんどみられずほぼ同じ挙動を示した (図 $5 \sim 7$ ).

3-3 粉液比の変化 $(\mathrm{L} / \mathrm{P}=1.11)$ による影響

粉液比の影響は， $\mathrm{L} l \mathrm{D} l$ 試料についてのみ検討をおこ なつた. $\mathrm{L} / \mathrm{P}$ 比を 1.11 にした試料の収縮量は, $\mathrm{L} / \mathrm{P}$ 比 を 0.56 にした試料の収縮量の約 2 倍の值を示した（図 11). これによると $\mathrm{L} / \mathrm{P}=1.11$ とした試料の鋳込口より $44 \mathrm{~mm}$ のところの収縮 量は, $\mathrm{L} / \mathrm{P}=0.56$ の試料の最大 収縮量（鋳込口から $100 \mathrm{~mm}$ のところで約 $1.34 \mathrm{~mm}$ ) と同じとなつた.またこの試料の $100 \mathrm{~mm}$ での収縮量 は約 $2.74 \mathrm{~mm}$ であつた. このグラフを図上微分するこ とによつて求めた収縮の変化率でも鋳込口付近では，著 しく高い值を示したが，鋳込口より遠さかるに従つて急 激な低下を示した（図 12）。

\section{3-4 重合後の経時的変化}

メーカ指示に従つて重合したレジン片を室温 $\left(25^{\circ} \mathrm{C}\right)$ で 30 分間泠却したものと，室温中に 48 時間放置したも のとの間の線ひずみ率を比較した（図 13).これによる と体積の小さいもの程大きい値を示し, $2 \sim 3 \mathrm{~cm}^{3}$ 以上 の体積ではほぼ一定した值 (0.8) を示した.

\section{4. 考察}

以上の実験結果より，寒天鋳型中に流し込まれるレジ

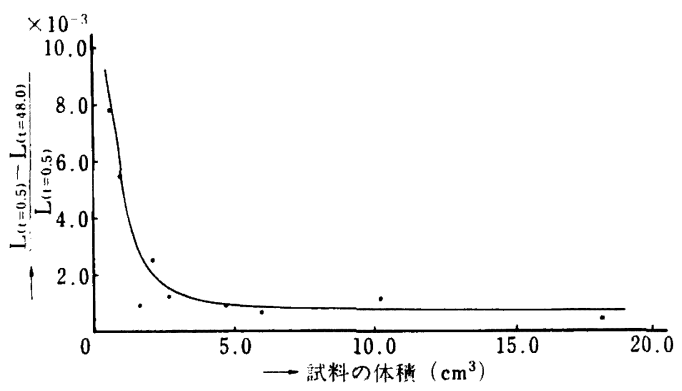

図 13 重合後の試料收縮量の経時的変化

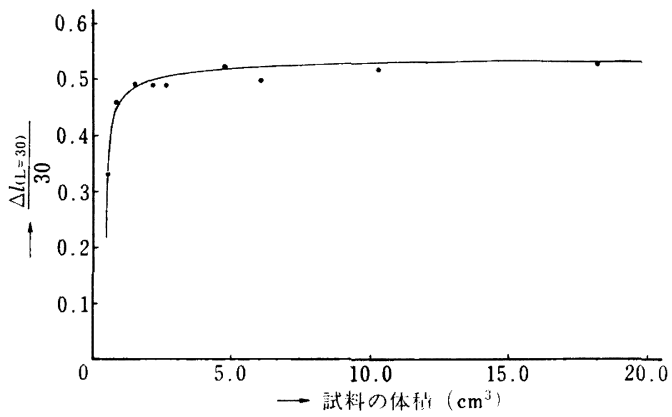

図 14 重合時の試料収縮率

ンの量が多くなるに従つて重合時に生ずるレジンの収縮 量は大きくなつている（図 5〜7). また各試料の鋳込 ロからの収縮率（図 8～10）は，いずれの径の場合もレ ジン片の長さが長くなるに従つて大きくなる. このこと は，重合時に生ずる反応熱が周囲の寒天にうばわれ，十 分な重合がなされないためと思われる．図 14 は，実験 結果をもとにして鋳込口より $30 \mathrm{~mm}$ のところまでの収 縮量と使用したレジン量との関係を図示したものであ る.これによると収縮率は, レジンの使用量が $2 \sim 3 \mathrm{~cm}^{3}$ までは，使用量が増すに従つて著しく大きくなる．それ 以上の使用量では収縮率はほとんど変化なく一定した值 を示すようになる. 従つてレジンに十分な重合反応をお こさせるには，本実験のような棒状試験片の場合でも， $2 \sim 3 \mathrm{~cm}^{3}$ 以上のレジンが必要であることが予想される. レジン重合時の収縮率は，L/P 比の影響を受け易く， L/P が大きくなると収縮量も著しく大きくなる（図 11）. $\mathrm{L} / \mathrm{P}$ と収縮量との関係, あるいは L/P を大きくした場合 レジンの重合反応がメーカ指示に従つての重合条件下で 十分進みうるための最低量等については本実験では十分 な考察ができないが，かなりの Mass を必要とするも のと思われる.

本実験では，単純な棒状レジン片の収縮をとりあつか 
$42-42$

つたが，実際臨床で使用する場合は厚さが不均一である とともに複雑な形状を呈している.したがつて重合した レジンも部位によつてかなり収縮率に差があるものと推 測される、図 13 はメーカ指示にしたがつて重合したレ ジンを $25^{\circ} \mathrm{C}$ の空気中に 48 時間おき, その間の収縮量と 使用したレジン量との関係を図示したものであるが，こ れによると体積が小さい試料ほど重合操作後 48 時間に みられる収縮量は大きくなつている，したがつて重合時 の収縮量が小さい試料，すなわち重合が不十分でかなり の残留 Monomer を含むと思われる試料程, 通法の重 合操作後に大きな収縮がみられることになる（図 13， 14).この重合操作後にみられる収縮あるいはレジンの 厚さの不均一によつて生ずる収縮率の差は, 重合後の重 合体を変形させる大きな要因の 1 つになりうるため, 流 し込みレジンを使用する場合には十分メーカ指示の重合 温度に保つておくことが必要であると考える.

\section{5. 結論}

以上の考察をまとめると, 次のように結論ゔけられ る.

1. 粉液比 (L/P) を 2 倍にすると収縮量もおよそ 2 倍になるため，適合性のよい重合体を得るためには，キ ヤストする上に支障がない限り Monomer 量を少なく することが望ましい.

2. 重合体の収縮率は, 鋳込口の方が大きく, 鋳込口 より遠ざかるにしたがつて小さくなる.

3. 体積が小さいもの程, 重合操作時に生ずる重合体 の収縮率は小さくなる。

4. 体積が小さいもの程, 重合してから後の重合体の 収縮率は大きくなる。

本実験では，棒状レジン片の長軸方向への収縮だけを とり上げ, 長さの依存性, 径の依存性を 2 通りの粉液比
で調べ，重合体の変形の原因について考察した。しかし 臨床における義歯床の変形を吟味するには，一軸方向の 収縮だけでは十分な検討ができない，したがつて，今後 種々の形状のレジン片を用いて 3 軸方向での収縮で検討 を重ねていく予定である.

\section{文献}

1) Winkler, S. : Pour technique for denture base processing, Dent. dig., $73:$ 200 203, 1967.

2) Shepard, W.L.: Denture bases processed from a fluid resin, J. Pros. Dent., $19: 561 \sim 572,1968$.

3）鈴木暎ほか：寒天型レジン重合の二三の問題, 歯材器誌 $29: 74 \sim 80,1973$.

4) Goodkind, R.J. et al. : Dimentional accuracy of pour acrylic resin and conventional processing of cold-curing acrylic resin bases, J. Pros. Dent., $24: 662 \sim 668,1970$

5）松本值之ほか：流し込みレジンの加工精度，補綴臨床， 4 (1), $117 \sim 123,1971$.

6）安田登ほか：流し込みレジンのスプルーの形態と重合収 縮. 人工歯の移動，歯界展望, 44 (4)，498 504， 1974.

7）岸野常朝 : 流し込み形床用レジン（キャストレジン）に 関する基整的検討, 歯材器誌, 31 (4):259 268, 1974.

8）奥野善彦ほか：注入型レジン床義歯の経過観察からみた 問題点とその対策，歯界展望，44 (2), 219 227, 1974.

9）安田登ほか：流し込みレジンによる正確な義崡床の製作 法, 歯理工誌, 15 (33), 205 210, 1974 .

10) Grant, A.A. : Comparison between dimensional accuracy of dentures prodused with pour type resin and with heatprocessed materiales, J. Pros. Dent.,26:296 301, 1971.

11）熱田充ほか：流し込み法による正確なレジン床のつくり 方, DE, 17 (4), 4 13, 1971. 